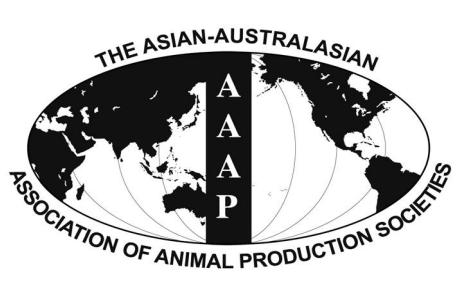

Open Access

Asian Australas. J. Anim. Sci.

Vol. 28, No. 10 : 1419-1426 October 2015

http://dx.doi.org/10.5713/ajas.15.0025

www.ajas.info

pISSN 1011-2367 elSSN 1976-5517

\title{
Effect of the Ratio of Non-fibrous Carbohydrates to Neutral Detergent Fiber and Protein Structure on Intake, Digestibility, Rumen Fermentation, and Nitrogen Metabolism in Lambs
}

\author{
T. Ma, Y. Tu, N. F. Zhang, K. D. Deng', and Q. Y. Diao* \\ Feed Research Institute, Chinese Academy of Agricultural Sciences, \\ Key Laboratory of Feed Biotechnology of Ministry of Agriculture, Beijing 100081, China
}

\begin{abstract}
This study aimed to investigate the effect of the ratio of non-fibrous carbohydrates to neutral detergent fibre (NFC/NDF) and undegraded dietary protein (UDP) on rumen fermentation and nitrogen metabolism in lambs. Four Dorper $\times$ thin-tailed Han crossbred lambs, averaging $62.3 \pm 1.9 \mathrm{~kg}$ of body weight and $10 \mathrm{mo}$ of age, were randomly assigned to four dietary treatments of combinations of two levels of NFC/NDF (1.0 and 1.7) and two levels of UDP (35\% and $50 \%$ of crude protein [CP]). Duodenal nutrient flows were measured with dual markers of $\mathrm{Yb}$ and $\mathrm{Co}$, and microbial $\mathrm{N}(\mathrm{MN})$ synthesis was estimated using ${ }^{15} \mathrm{~N}$. High UDP decreased organic matter $(\mathrm{OM})$ intake $(\mathrm{p}=0.002)$ and $\mathrm{CP}$ intake $(\mathrm{p}=0.005)$. Ruminal $\mathrm{pH}(\mathrm{p}<0.001)$, ammonia nitrogen $\left(\mathrm{NH}_{3}-\mathrm{N} ; \mathrm{p}=0.008\right)$, and total volatile fatty acids $(\mathrm{p}<0.001)$ were affected by dietary NFC/NDF. The ruminal concentration of $\mathrm{NH}_{3}-\mathrm{N}$ was also affected by UDP $(\mathrm{p}<0.001)$. The duodenal flow of total MN ( $\mathrm{p}=0.007)$ was greater for lambs fed the high NFC/NDF diet. The amount of metabolisable $\mathrm{N}$ increased with increasing dietary NFC:NDF $(\mathrm{p}=0.02)$ or UDP $(\mathrm{p}=0.04)$. In conclusion, the diets with high NFC/NDF (1.7) and UDP (50\% of CP) improved metabolisable N supply to lambs. (Key Words: Non-fibrous Carbohydrate, Neutral Detergent Fibre, Undegraded Dietary Protein, Metabolisable N, Lambs)
\end{abstract}

\section{INTRODUCTION}

Reduction of $\mathrm{N}$ excretion to the environment has drawn increasing concern in recent years as inputs of ammonia have increased by more than $50 \%$ since 1950 (Asman et al., 1998). Intensive animal production systems are responsible for this change as farm manure has been identified as a major source of nitrate pollution (Lord, 1996), which poses a threat to the quality of water, air, soil, and ultimately human health. Globally, the size of livestock production is still increasing because of the rising demands for highquality animal products. Therefore, $\mathrm{N}$ losses from livestock production are of great importance.

The $\mathrm{N}$ output of livestock production systems can be

\footnotetext{
* Corresponding Author: Q. Y. Diao. Tel: +86-10-82106055, Fax: +86-10-62169105, E-mail: diaoqiyu@caas.cn

${ }^{1}$ College of Animal Science, Jinling Institute of Technology, Nanjing, Jiangsu 210038, China.

Submitted Jan. 8, 2015; Revised Apr. 6, 2015; Accepted Apr. 20, 2015
}

reduced by improving $\mathrm{N}$ utilisation by animals (Hoekstra et al., 2007). In ruminants, the asynchrony between the degradation rate of carbohydrates and proteins in the rumen lowers N utilisation efficiency (Stern et al., 1994). Although such an asynchrony can be partly overcome by use of protein supplements, elevated feed costs and further reduced $\mathrm{N}$ utilisation could be expected. Optimising ruminal fermentation and increasing microbial protein production in the rumen can be achieved by manipulation of dietary carbohydrates as well as proteins (Clark et al., 1992). An increase in non-fibrous carbohydrates (NFC) can be implemented by elevating concentrate levels, improved feed intake, nutrient digestibility, and microbial protein synthesis in the rumen (Ramos et al., 2009). However, in previous studies, the influence of dietary protein was not taken into consideration, and therefore, it is unclear whether factors such as protein components (ruminal degraded protein/undegraded dietary protein, RDP/UDP) had influences on those indices, as Reynal and Broderick (2005) 
reported that increasing dietary UDP to a certain level decreased feed intake and microbial $\mathrm{N}(\mathrm{MN})$ in cattle.

This study aimed to investigate whether dietary NFC/NDF and UDP influences $\mathrm{N}$ metabolism, especially duodenal N utilisation in Dorper $\times$ thin-tailed Han crossbred lambs used for lamb meat production in China. We hypothesised that the level of NFC and UDP could act collectively on $\mathrm{N}$ metabolism.

\section{MATERIALS AND METHODS}

\section{Animals and dietary treatments}

This study was conducted from July 2013 to November 2013 at the Experimental Station of the Chinese Academy of Agricultural Sciences (CAAS), Beijing, China. The experimental procedures were approved by the Animal Ethics Committee of CAAS, and humane animal care and handling procedures were followed throughout the experiment.

Four 10-month-old Dorper $\times$ thin-tailed Han crossbred non-castrated ram lambs $(62.3 \pm 1.9 \mathrm{~kg}$ body weight) were surgically fitted with ruminal and duodenal cannula and were used in this study approximately 6 mo after the surgery. The lambs were randomly assigned to four dietary treatments, including two levels of NFC ( $40 \%$ and $50 \%$ of dry matter $[\mathrm{DM}])$ and UDP (35\% and $50 \%$ of crude protein $[\mathrm{CP}])$ according to a $4 \times 4$ Latin-square experimental design. Experimental diets were iso-nitrogenous and iso-energetic. The ingredients and chemical composition of the experimental diets are presented in Table 1. Lambs were fed twice daily at 08:00 $\mathrm{h}$ and 16:00 $\mathrm{h}$ with ad libitum intake, allowing for approximately $10 \%$ refusal. Clean water was available at all times. Each experimental period lasted for $24 \mathrm{~d}$. The first $7 \mathrm{~d}$ were used for adaptation to the dietary treatment, and the lambs were then moved into individual metabolism crates for $12 \mathrm{~d}$, including $7 \mathrm{~d}$ of adaption and 5 $\mathrm{d}$ of a digestibility trial. Finally the duodenal and ruminal digesta were sampled consecutively for $5 \mathrm{~d}$.

$\mathrm{Yb}$ and $\mathrm{Co}$ were used as the markers for particulate and liquid phases in the rumen, respectively, to determine the flow of digesta from the rumen to the duodenum. Simultaneously, ${ }^{15} \mathrm{~N}$ was used as an external microbial marker. All markers were mixed with the concentrate prior to pelleting (Ma et al., 2013). Approximately $1.44 \mathrm{~kg}$ of $\mathrm{YbCl}_{3} \cdot 6 \mathrm{H}_{2} \mathrm{O}$ and $4.32 \mathrm{~kg}$ of Li-Co-EDTA $(2.92 \mathrm{~kg}$ of $\mathrm{C}_{4} \mathrm{H}_{6} \mathrm{O}_{4} \cdot \mathrm{Co} \cdot \mathrm{H}_{2} \mathrm{O}, 3.42 \mathrm{~kg}$ of EDTA, and $500 \mathrm{~g}$ of $\mathrm{LiOH}$ ) and $1.08 \mathrm{~kg}$ of $\left({ }^{15} \mathrm{NH}_{4}\right)_{2} \mathrm{SO}_{4}\left({ }^{15} \mathrm{~N}, 10 \%\right.$ of atoms) was dissolved in $40 \mathrm{~L}$ of deionised water and then sprayed on $1.44 \mathrm{~kg}$ of concentrate diet before pelleting. Daily marker consumption approximated $500 \mathrm{mg}$ of $\mathrm{Yb}$ and $\mathrm{Co}$ and 20 $\mathrm{mg}$ of ${ }^{15} \mathrm{~N}$ for each lamb. Prior to offering the marked feed, a priming dose of half of the daily marker intake was administered through the rumen cannula of each animal
Table 1. Ingredients and chemical compositions of experimental diets $(\%$ of DM)

\begin{tabular}{|c|c|c|c|c|}
\hline \multirow{3}{*}{ Item } & \multicolumn{2}{|c|}{ Low NFC/NDF } & \multicolumn{2}{|c|}{ High NFC/NDF } \\
\hline & High & Low & High & Low \\
\hline & UDP & UDP & UDP & UDP \\
\hline \multicolumn{5}{|l|}{ Ingredient } \\
\hline Ground corn & 28.72 & 32.57 & 50.59 & 57.29 \\
\hline Soybean meal & 0.00 & 5.50 & 0.00 & 0.25 \\
\hline Chinese wildrye hay & 60.00 & 60.00 & 40.00 & 40.00 \\
\hline Corn gluten meal & 10.00 & 0.00 & 7.90 & 0.00 \\
\hline Urea & 0.00 & 0.65 & 0.00 & 1.00 \\
\hline $\mathrm{CaHPO}_{4}$ & 0.50 & 0.50 & 0.25 & 0.00 \\
\hline Limestone & 0.12 & 0.12 & 0.60 & 0.80 \\
\hline $\mathrm{NaCl}$ & 0.50 & 0.50 & 0.50 & 0.50 \\
\hline Premix $^{a}$ & 0.16 & 0.16 & 0.16 & 0.16 \\
\hline \multicolumn{5}{|l|}{ Chemical component } \\
\hline DM (\% as fed $)$ & 89.72 & 89.65 & 88.85 & 88.11 \\
\hline $\mathrm{OM}(\%$ of $\mathrm{DM})$ & 93.67 & 92.91 & 94.62 & 94.75 \\
\hline $\mathrm{GE}(\mathrm{KJ} / \mathrm{g}$ of $\mathrm{DM})$ & 18.32 & 18.47 & 18.43 & 18.50 \\
\hline $\mathrm{CP}(\%$ of $\mathrm{DM})$ & 10.42 & 10.46 & 10.40 & 10.49 \\
\hline $\mathrm{EE}(\%$ of $\mathrm{DM})$ & 2.66 & 2.60 & 3.17 & 3.21 \\
\hline $\mathrm{RDP}(\% \text { of } \mathrm{DM})^{\mathrm{b}}$ & 4.85 & 6.41 & 4.74 & 6.65 \\
\hline $\operatorname{UDP}(\% \text { of } \mathrm{DM})^{\mathrm{c}}$ & 5.57 & 4.04 & 5.68 & 3.96 \\
\hline $\mathrm{UDP} / \mathrm{CP}$ & 0.53 & 0.39 & 0.55 & 0.37 \\
\hline NDF ( $\%$ of DM) & 41.33 & 39.19 & 30.52 & 29.58 \\
\hline $\mathrm{ADF}(\%$ of $\mathrm{DM})$ & 24.10 & 23.94 & 17.09 & 16.60 \\
\hline NFC $(\% \text { of DM })^{d}$ & 39.26 & 40.66 & 50.53 & 51.47 \\
\hline $\mathrm{NFC/NDF}$ & 0.95 & 1.04 & 1.65 & 1.74 \\
\hline
\end{tabular}

NFC, non-fibrous carbohydrates; NDF, neutral detergent fibre; UDP, undegraded dietary protein; DM, dry matter; OM, organic matter; GE, gross energy; $\mathrm{CP}$, crude protein; EE, ether extract; RDP, rumen-degraded protein; ADF, acid-detergent fibre.

a Manufactured by the Precision Animal Nutrition Research Centre, Beijing, China. One kilogram of mineral premix contained the following: $\mathrm{CuSO}_{4} \cdot 5 \mathrm{H}_{2} 0,26,000 \mathrm{mg} ; \mathrm{FeSO}_{4}, 110,000 \mathrm{mg} ; \mathrm{MnSO}_{4} \cdot \mathrm{H}_{2} \mathrm{O}, 93,000 \mathrm{mg}$; $\mathrm{ZnSO}_{4} \cdot \mathrm{H}_{2} \mathrm{O}, 190,000 \mathrm{mg} ; \mathrm{KI}, 70,000 \mathrm{mg} ; \mathrm{Na}_{2} \mathrm{SeO}_{3}, 42,000 \mathrm{mg} ; \mathrm{CoCl}_{2}$, $20,000 \mathrm{mg}$. One kilogram of vitamin premix contained the following: vitamin A 190,000,000 IU; vitamin $\mathrm{D}_{3}$ 720,000,000 IU; vitamin E 17,000 IU.

${ }^{\mathrm{b}}$ RDP were estimated using an in situ method by incubating samples in the rumen for $72 \mathrm{~h}$ as described by Volden and Harstad (1995).

${ }^{\mathrm{c}} \mathrm{UDP}=\mathrm{CP}-\mathrm{RDP}$

${ }^{\mathrm{d}} \mathrm{NFC}=\mathrm{OM}-\mathrm{CP}-\mathrm{EE}-\mathrm{NDF}$ (Hall, 2000).

(Ma et al., 2013).

\section{Measurements and sample collection}

In the digestibility trial, faecal samples were collected daily from days 16 to 20 . Faecal samples were weighed daily, and then, a $10 \%$ sample was collected. The samples were pooled for each animal, dried at $65^{\circ} \mathrm{C}$, and then ground through a $1-\mathrm{mm}$ sieve before analysis. Urine from each lamb was also collected daily in a bucket containing $100 \mathrm{~mL}$ of $7.2 \mathrm{NH}_{2} \mathrm{SO}_{4}$. The volume was measured and then diluted to $5 \mathrm{~L}$ with tap water, and a sample of $20 \mathrm{~mL}$ was collected, pooled for each animal, and stored at $-20^{\circ} \mathrm{C}$ for 
the analysis of total $\mathrm{N}$. The samples of feed were also collected daily, combined, dried at $65^{\circ} \mathrm{C}$ for $72 \mathrm{~h}$, and ground through a $1-\mathrm{mm}$ sieve. Feed refusals were also weighed, sampled, dried, ground, and combined for each lamb before analysis.

From days 21 to 23 , a $100-\mathrm{mL}$ sample of duodenal digesta was collected every $6 \mathrm{~h}$, moving the collection time forward $2 \mathrm{~h}$ each day to obtain the samples at 2-h intervals (i.e., 08:00, 14:00, and 20:00 on day 21;02:00, 06:00, 12:00, 18:00, and 24:00 hours on day 22; and 04:00, 10:00, 16:00, and 22:00 on day 23). The duodenal digesta were frozen at $-20^{\circ} \mathrm{C}$ and thawed before analysis, and a volume of $800 \mathrm{~mL}$ was separated into particulate and liquid fractions as described by Ma et al. (2013). Nutrient concentrations and markers were determined in each fraction for the apparent ruminal digestibility of nutrients and the digesta flow from the rumen to the duodenum. An additional sample of the duodenal digesta $(10 \mathrm{~mL})$ was centrifuged at $20,000 \mathrm{~g}, 4^{\circ} \mathrm{C}$ for $20 \mathrm{~min}$, and the supernatant was stored for analysis of ammonia N.

Samples of ruminal digesta $(300 \mathrm{~mL})$ were collected at 6-h intervals from days 24 to 25 for the determination of ruminal fermentation parameters and $\mathrm{MN}$ (i.e., 08:00, 14:00, and 20:00 on day 24; and 02:00, 05:00, 11:00, 17:00, and 23:00, on day 25). The ruminal samples were obtained through the cannula from five different sites within the rumen using a syringe attached to a plastic tube $(20-\mathrm{mm}$ internal diameter). The $\mathrm{pH}$ of the digesta was measured immediately using a pH metre (Model PB-10, Sartorius Co., Gottingen, Germany). Thereafter, approximately $50 \mathrm{~mL}$ of the digesta was filtered through one layer of cheesecloth. A 10-mL sample of the strained fluid was collected, acidified with $2 \mathrm{~mL} \mathrm{25 \% (w/v)} \mathrm{metaphosphoric} \mathrm{acid,} \mathrm{and} \mathrm{stored}$ frozen at $-20^{\circ} \mathrm{C}$ for analysis of volatile fatty acids (VFA) and ammonia nitrogen $\left(\mathrm{NH}_{3}-\mathrm{N}\right)$. The remaining $250 \mathrm{~mL}$ of digesta was used to separate out a bacterial pellet through differentiated centrifugation, and the procedures were the same as described by Ma et al. (2013). The pellet was transferred into a centrifuge tube with a minimum amount of distilled water and stored at $-20^{\circ} \mathrm{C}$ for analysis of total $\mathrm{N}$ and ${ }^{15} \mathrm{~N}$ enrichment.

\section{Chemical analysis}

DM (method 930.15), organic matter (OM; method 967.05), CP (method 977.02), ether extract (EE; method 920.39) and ash (method 942.05) were measured according to the Association of Official Analytical Chemists methods (AOAC, 1990). Neutral detergent fibre (NDF) and aciddetergent fibre (ADF) were determined according to Van Soest et al. (1991) and Goering and Van Soest (1970), respectively. Dietary components of RDP were estimated using an in situ method by incubating samples in the rumen for $72 \mathrm{~h}$ as described by Volden and Harstad (1995).
Ruminal VFA were measured with a flame ionisation detector in a gas chromatograph (GC522, Wufeng Instruments, Shanghai, China) using a $15-\mathrm{mL}$ semicapillary glass column $(0.53 \mathrm{~mm}$ in diameter $)$ packed with Chromosorb 101 (Johns-Monville, Denver, CO, USA) with $\mathrm{N}_{2}$ as carrier gas at a column temperature of $120^{\circ} \mathrm{C}$. Before analysis, caproic acid was added to each sample as an internal standard. Ammonia $\mathrm{N}$ was assessed by the colorimetric method of Chaney and Marbach (1962). The isotopic abundance of ${ }^{15} \mathrm{~N}$ in bacterial $\mathrm{N}$ and duodenal fractions was determined by isotope ratio mass spectrometry (Finnigan Mat 251, Thermo Fisher Scientific Inc., San Jose, CA, USA). The concentration of $\mathrm{Yb}$ and $\mathrm{Co}$ in the digesta was determined by inductively coupled plasma emission spectrometry (X series 2 ICP-MS, Thermo Fisher Scientific Inc., Waltham, MA, USA).

\section{Calculations and statistical analysis}

Duodenal flows of nutrients were determined by reconstitution of the duodenal digesta based on $\mathrm{Yb}$ and $\mathrm{Co}$ concentrations and the content of the nutrients in the particulate and whole fractions. $\mathrm{MN}$ in the duodenum was determined by using ${ }^{15} \mathrm{~N}$ as an external microbial marker. For the calculation of $\mathrm{MN}$ yield with ${ }^{15} \mathrm{~N}$, the microbial non-ammonia $\mathrm{N}$ (NAN) flow to the duodenum was estimated as follows:

$$
\mathrm{MN} / \mathrm{NAN}_{\text {digesta }}=\left(\mathrm{E}-\mathrm{NAN} \mathrm{N}_{\text {digesta }}\right) /\left(\mathrm{E}-\mathrm{N}_{\text {bacteria }}\right)
$$

where $\left(\mathrm{E}-\mathrm{NAN} \mathrm{N}_{\text {digesta }}\right)$ and $\left(\mathrm{E}-\mathrm{N}_{\text {bacteria }}\right)$ are the ${ }^{15} \mathrm{~N}$ enrichments of digesta NAN and rumen bacterial $\mathrm{N}$, respectively. Based on the observation that the natural abundance of ${ }^{15} \mathrm{~N}$ from ruminal microbes and duodenal digesta was similar (Ahvenjärvi et al., 2002), duodenal digesta samples were analysed for ${ }^{15} \mathrm{~N}$ before using marked feed, and a value of 0.363 was taken as the ${ }^{15} \mathrm{~N}$ background for both the microbial and duodenal digesta.

Metabolisable $\mathrm{N}=$ total $\mathrm{NAN}-($ faecal $\mathrm{N}+$ endogenous N)

Endogenous $\mathrm{N}$ was calculated as $2.8 \mathrm{~g} \mathrm{~N} / \mathrm{kg}$ DM intake according to Bartram (1987).

Data were analysed as a mixed model using MIXED procedure of SAS (version 9.1; SAS Institute, Inc., Cary, NC, USA). The statistical model is shown below:

$$
\mathrm{Y}=\mu+\alpha+\beta+\gamma(\alpha)+c+\varepsilon
$$

where $\mu$ is the overall mean; $\alpha$ is the random effect of the square; $\beta$ is the random effect of period; $\gamma(\alpha)$ is the random effect of lamb within the square; $c$ is the fixed effect of treatment, and $\varepsilon$ is the random error.

Observations of the ruminal $\mathrm{pH}, \mathrm{VFA}$, and ammonia $\mathrm{N}$ were analysed as repeated measures. The statistical model is 
shown below:

$$
\mathrm{Y}=\mu+\alpha+\beta+\gamma(\alpha)+c+t+c \times t+\varepsilon
$$

where $\mu, \alpha, \beta, \gamma(\alpha)$, and $c$ are described as above; $t$ is the effect of time; $c \times t$ is the interaction between treatment and time, and $\varepsilon$ is the random error. Data for each variable were analysed using compound symmetry, unstructured, and autoregressive covariance structures. The test that satisfied the minimum Akaike's information criterion was chosen. Effects were declared significant when $\mathrm{p}<0.05$.

\section{RESULTS}

\section{Nutrient intake and digestibility}

Decreasing dietary UDP increased OM intake ( $\mathrm{p}=$ $0.002)$ and $C P$ intake $(p=0.005)$. Intake of $E E$ was increased $(p=0.04)$ but that of NDF $(p=0.009)$ and ADF $(\mathrm{p}=0.004)$ was reduced in lambs fed high NFC/NDF diets (Table 2). On the other hand, dietary NFC/NDF had no effect on intake of $\mathrm{OM}(\mathrm{p}=0.82)$ or $\mathrm{CP}(\mathrm{p}=0.17)$, and dietary UDP had no effect on intake of EE $(p=0.30)$, NDF $(p=0.36)$, or ADF $(p=0.41)$. No interaction was observed on the above nutrient intakes ( $\mathrm{p}>0.05)$.

Increasing dietary NFC/NDF increased total-tract apparent digestibility of OM $(p=0.005)$ and $\mathrm{EE}(\mathrm{p}=0.005)$ but decreased that of ADF $(p<0.001)$. Dietary NFC/NDF had no effect on total-tract digestibility of $\mathrm{CP}(\mathrm{p}=0.67)$ or NDF $(p=0.85)$. Dietary UDP and dietary interactions had no effect $(p>0.05)$ on total-tract digestibility of all nutrients.

The ruminal digestibility of $\mathrm{OM}$ was not affected by dietary NFC/NDF $(p=0.65)$ or UDP $(p=0.47)$. Dietary NFC/NDF decreased ruminal digestibility of $\mathrm{CP}(\mathrm{p}<0.001)$, NDF $(p=0.03)$, and ADF $(p<0.001)$. High dietary UDP decreased ruminal digestibility of $C P(p<0.001)$. Dietary UDP had no effect on ruminal digestibility of NDF ( $p=$ $0.13)$ or $\operatorname{ADF}(p=0.26)$. The effect of treatment interactions on ruminal digestibility of $\mathrm{CP}(\mathrm{p}<0.001)$ was observed.

High dietary NFC/NDF increased post-ruminal digestibility of OM $(p<0.001), \mathrm{CP}(\mathrm{p}=0.02)$, and NDF $(\mathrm{p}<0.001)$. High dietary UDP only increased post-ruminal digestibility of CP $(p=0.03)$. Dietary interactions were also observed in post-ruminal digestibility of $\mathrm{CP}(\mathrm{p}=0.02)$.

\section{Ruminal characteristics}

Ruminal $\mathrm{pH}$ and $\mathrm{NH}_{3}-\mathrm{N}$ were decreased by high

Table 2. Effects of dietary NFC/NDF and UDP on intake and digestibility of nutrients in lambs

\begin{tabular}{|c|c|c|c|c|c|c|c|c|}
\hline \multirow{2}{*}{ Item } & \multicolumn{2}{|c|}{ Low NFC/NDF } & \multicolumn{2}{|c|}{ High NFC/NDF } & \multirow{2}{*}{ SEM } & \multicolumn{3}{|c|}{ p-value } \\
\hline & High UDP & Low UDP & High UDP & Low UDP & & $\mathrm{NFC/NDF}$ & UDP & Interaction $^{\mathrm{a}}$ \\
\hline \multicolumn{9}{|c|}{ Intake (g/d) } \\
\hline $\mathrm{OM}$ & $1,395.8$ & $1,501.0$ & $1,349.3$ & $1,460.3$ & 143.0 & 0.82 & 0.002 & 0.27 \\
\hline $\mathrm{CP}$ & 155.3 & 169.0 & 148.3 & 161.7 & 12.43 & 0.17 & 0.005 & 0.22 \\
\hline $\mathrm{EE}$ & 39.64 & 42.00 & 45.20 & 49.47 & 2.49 & 0.04 & 0.30 & 0.61 \\
\hline $\mathrm{NDF}$ & 615.9 & 633.1 & 435.2 & 455.9 & 40.5 & 0.009 & 0.36 & 0.54 \\
\hline $\mathrm{ADF}$ & 359.1 & 386.8 & 243.7 & 255.8 & 20.4 & 0.004 & 0.41 & 0.52 \\
\hline \multicolumn{9}{|c|}{ Total-tract digestibility (\%) } \\
\hline $\mathrm{OM}$ & 55.90 & 57.92 & 63.38 & 64.57 & 1.31 & 0.005 & 0.43 & 0.84 \\
\hline $\mathrm{CP}$ & 65.13 & 66.82 & 66.24 & 67.50 & 1.47 & 0.67 & 0.79 & 0.95 \\
\hline $\mathrm{EE}$ & 71.58 & 72.18 & 80.38 & 81.86 & 1.52 & 0.005 & 0.54 & 0.75 \\
\hline $\mathrm{NDF}$ & 51.89 & 52.98 & 51.04 & 55.62 & 2.07 & 0.85 & 0.56 & 0.72 \\
\hline $\mathrm{ADF}$ & 47.93 & 48.77 & 34.49 & 37.66 & 2.17 & $<0.001$ & 0.25 & 0.54 \\
\hline \multicolumn{9}{|c|}{ Ruminal digestibility (\%) } \\
\hline $\mathrm{OM}$ & 40.74 & 40.15 & 39.84 & 39.17 & 0.37 & 0.65 & 0.47 & 0.52 \\
\hline $\mathrm{CP}$ & 11.8 & 21.6 & -0.40 & 12.4 & 1.75 & $<0.001$ & $<0.001$ & $<0.001$ \\
\hline $\mathrm{EE}$ & 46.17 & 43.58 & 41.16 & 43.61 & 1.36 & 0.25 & 0.02 & 0.26 \\
\hline $\mathrm{NDF}$ & 50.83 & 51.01 & 42.63 & 40.86 & 1.77 & 0.03 & 0.13 & 0.33 \\
\hline $\mathrm{ADF}$ & 44.92 & 44.59 & 35.04 & 36.91 & 4.01 & $<0.001$ & 0.26 & 0.41 \\
\hline \multicolumn{9}{|c|}{ Post-ruminal digestibility (\%) } \\
\hline $\mathrm{OM}$ & 15.17 & 17.77 & 23.55 & 25.40 & 2.02 & $<0.001$ & 0.23 & 0.31 \\
\hline $\mathrm{CP}$ & 53.4 & 45.2 & 66.6 & 55.1 & 3.13 & 0.02 & 0.03 & 0.02 \\
\hline $\mathrm{EE}$ & 25.38 & 28.55 & 39.27 & 38.23 & 1.98 & 0.65 & 0.54 & 0.75 \\
\hline $\mathrm{NDF}$ & 1.06 & 1.98 & 8.41 & 14.75 & 3.02 & $<0.001$ & 0.13 & 0.33 \\
\hline $\mathrm{ADF}$ & 3.02 & 4.19 & -0.55 & 0.75 & 0.91 & 0.17 & 0.26 & 0.41 \\
\hline
\end{tabular}

NFC, non-fibrous carbohydrates; NDF, neutral detergent fibre; SEM, scanning electron microscope; UDP, undegraded dietary protein; OM, organic matter; $\mathrm{CP}$, crude protein; EE, ether extract; ADF, acid-detergent fibre.

${ }^{a}$ Interaction of dietary NFC/NDF and UDP. 
Table 3. Effect of dietary NFC/NDF and UDP on ruminal fermentation parameters in lambs

\begin{tabular}{|c|c|c|c|c|c|c|c|c|}
\hline \multirow{2}{*}{ Item } & \multicolumn{2}{|c|}{ Low NFC/NDF } & \multicolumn{2}{|c|}{ High NFC/NDF } & \multirow{2}{*}{ SEM } & \multicolumn{3}{|c|}{ p-value } \\
\hline & High UDP & Low UDP & High UDP & Low UDP & & $\mathrm{NFC/NDF}$ & UDP & Interaction $^{\mathrm{a}}$ \\
\hline$\overline{\mathrm{pH}}$ & 6.15 & 6.07 & 5.87 & 5.90 & 0.05 & $<0.001$ & 0.53 & 0.34 \\
\hline $\mathrm{NH}_{3}-\mathrm{N}(\mathrm{mg} / 100 \mathrm{~mL})$ & 11.0 & 16.7 & 8.6 & 11.2 & 1.08 & 0.008 & $<0.001$ & 0.005 \\
\hline Total VFA (mmol) & 92.7 & 96.9 & 103.2 & 105.7 & 2.32 & $<0.001$ & 0.27 & 0.51 \\
\hline \multicolumn{9}{|l|}{ VFA (mol/100 mol) } \\
\hline Acetate & 65.6 & 65.6 & 59.9 & 61.1 & 0.42 & 0.007 & 0.13 & 0.25 \\
\hline Propionate & 18.1 & 17.8 & 21.8 & 20.4 & 0.49 & $<0.001$ & 0.23 & 0.42 \\
\hline Butyrate & 14.1 & 14.0 & 15.6 & 16.1 & 0.21 & 0.003 & 0.35 & 0.31 \\
\hline Isobutyrate & 0.65 & 0.79 & 0.63 & 0.64 & 0.06 & 0.30 & 0.16 & 0.47 \\
\hline Valerate & 0.67 & 0.79 & 1.11 & 0.80 & 0.03 & 0.08 & 0.20 & 0.17 \\
\hline Isovalerate & 0.93 & 1.03 & 1.01 & 0.94 & 0.08 & 0.84 & 0.54 & 0.43 \\
\hline Acetate/propionate & 3.61 & 3.65 & 2.80 & 3.03 & 0.10 & $<0.001$ & 0.37 & 0.31 \\
\hline
\end{tabular}

NFC, non-fibrous carbohydrates; NDF, neutral detergent fibre; SEM, scanning electron microscope; UDP, undegraded dietary protein; $\mathrm{NH}_{3}-\mathrm{N}$, ammonia nitrogen; VFA, volatile fatty acid.

${ }^{a}$ Interaction of dietary NFC/NDF and UDP.

NFC/NDF diets $(\mathrm{p}<0.001$, Table 3$)$. In addition, ruminal $\mathrm{NH}_{3}-\mathrm{N}$ was greater for lambs fed low UDP diets than for those fed high UDP diets $(\mathrm{p}<0.001)$, and the interaction between treatments was also observed $(p=0.005)$. Dietary UDP had no effect on ruminal $\mathrm{pH}(\mathrm{p}=0.53)$ or total VFA ( $\mathrm{p}$ $=0.27)$. The ruminal total VFA $(p<0.001)$, proportion of propionate $(\mathrm{p}<0.001)$ and butyrate $(\mathrm{p}=0.003)$ were increased, whereas the proportion of acetate $(\mathrm{p}<0.001)$ and ratio of acetate to propionate $(p<0.001)$ were decreased by high NFC/NDF diets. Dietary NFC/NDF had no effect on the proportion of isobutyrate $(p=0.30)$ and dietary UDP had no effect on the molar proportion of VFA $(p>0.05)$.

\section{Duodenal $\mathbf{N}$ supply and $\mathbf{N}$ utilisation efficiency}

The duodenal flow of total NAN ( $p=0.03)$ and MN ( $p$ $=0.007)$ were greater for lambs fed high NFC/NDF diets
(Table 4). Dietary UDP had no effect on duodenal flow of total NAN $(p=0.12)$ and endogenous N $(p=0.57)$. Dietary NFC/NDF had no effect on duodenal flow of undegraded dietary $\mathrm{N}(\mathrm{p}=0.43)$ or endogenous $\mathrm{N}(\mathrm{p}=0.52)$. The duodenal flow of MN was also increased by low UDP diets $(\mathrm{p}=0.03)$. The amount of metabolisable $\mathrm{N}$ was increased by increasing dietary NFC/NDF $(p=0.02)$ or UDP $(p=$ $0.04)$, and treatment interaction was observed $(p=0.02)$. Faecal $\mathrm{N}$ was not affected by dietary treatments $(\mathrm{p}>0.05)$, and urinary $\mathrm{N}$ was lowered by high NFC/NDF $(\mathrm{p}=0.01)$ and high UDP diets $(p=0.04)$. The ratio of metabolisable $\mathrm{N}$ to total NAN was greater $(p=0.02)$ for high UDP diets (averaged 67.2\%) compared with that for low UDP diets (averaged 60.2\%). The ratio of metabolisable $\mathrm{N}$ to digestible $\mathrm{N}$ or to $\mathrm{N}$ intake was greater for high NFC/NDF diets $(p=0.02$ or 0.01$)$ and high UDP diets $(p=0.003$ or

Table 4. Effect of dietary NFC/NDF and UDP on duodenal supply and utilisation efficiency of protein in lambs

\begin{tabular}{|c|c|c|c|c|c|c|c|c|}
\hline \multirow{2}{*}{ Item } & \multicolumn{2}{|c|}{ Low NFC/NDF } & \multicolumn{2}{|c|}{ High NFC/NDF } & \multirow{2}{*}{ SEM } & \multicolumn{3}{|c|}{ p-value } \\
\hline & High UDP & Low UDP & High UDP & Low UDP & & NFC/NDF & UDP & Interaction $^{\mathrm{a}}$ \\
\hline \multicolumn{9}{|l|}{$\overline{\text { Duodenal flow (g/d) }}$} \\
\hline Total NAN & 21.92 & 21.20 & 23.82 & 22.88 & 0.24 & 0.03 & 0.12 & 0.37 \\
\hline Microbial N & 8.08 & 10.27 & 10.38 & 12.14 & 0.40 & 0.007 & 0.03 & 0.07 \\
\hline Undegraded dietary $\mathrm{N}$ & 13.28 & 10.45 & 12.96 & 9.76 & 0.41 & 0.43 & $<0.001$ & 0.45 \\
\hline Endogenous $\mathrm{N}^{\mathrm{b}}$ & 0.55 & 0.48 & 0.63 & 0.96 & 0.032 & 0.52 & 0.57 & 0.55 \\
\hline Metabolisable $\mathrm{N}^{\mathrm{c}}$ & 11.62 & 9.50 & 13.73 & 11.78 & 0.34 & 0.02 & 0.04 & 0.02 \\
\hline Faecal N (g/d) & 10.30 & 11.70 & 10.10 & 11.10 & 0.14 & 0.49 & 0.16 & 0.27 \\
\hline Urinary N (g/d) & 10.70 & 12.99 & 6.50 & 7.52 & 0.62 & 0.01 & 0.04 & 0.45 \\
\hline Metabolisable N/Total NAN (\%) & 65.5 & 57.0 & 69.2 & 63.4 & 1.18 & 0.35 & 0.02 & 0.49 \\
\hline Metabolisable N/Digestible N (\%) & 62.1 & 47.8 & 77.8 & 60.9 & 4.07 & 0.02 & 0.003 & 0.01 \\
\hline Metabolisable N/N intake (\%) & 46.7 & 35.1 & 57.8 & 45.1 & 2.35 & 0.01 & 0.006 & 0.01 \\
\hline
\end{tabular}

NFC, non-fibrous carbohydrates; NDF, neutral detergent fibre; SEM, scanning electron microscope; UDP, undegraded dietary protein; NAN, nonammonia $\mathrm{N}$.

${ }^{\mathrm{a}}$ Interaction of dietary NFC/NDF and UDP. ${ }^{\mathrm{b}}$ Endogenous N were calculated as $2.8 \mathrm{~g} / \mathrm{kg}$ DMI according to Bartram (1987).

${ }^{\mathrm{c}}$ Metabolisable $\mathrm{N}=$ Duodenal total NAN - Faecal $\mathrm{N}-$ endogenous $\mathrm{N}$. 
$0.006)$, and an interaction between treatments was observed $(\mathrm{p}=0.01)$.

\section{DISCUSSION}

\section{Nutrient intake}

The intake of OM was improved with decreasing UDP in the current study. The OM intake increased with decreasing UDP and ranged from 1.3 to $1.5 \mathrm{~kg} / \mathrm{d}$. These observations were in accordance with those of Kiran and Mutsvangwa (2007) who found that increasing dietary RDP from $60 \%$ to $70 \%$ of CP increased OM intake (ranging from 1.2 to $1.4 \mathrm{~kg} / \mathrm{d}$ ) in growing lambs. It has been reported that dietary RDP can promote intake by enhancing gastrointestinal motility (Egan and Moir, 1965).

Dietary NFC/NDF had no influence on OM intake in this trial. Commonly, an increase in dietary NFC can be achieved by increasing the level of concentrates. Therefore, the results of the current study are comparable with those obtained by Cantalapiedra-Hijar et al. (2009) and Ramos et al. (2009), who found no effect of dietary concentrate:forage ratios (30:70 and 70:30) on OM intake in both goats and sheep fed above maintenance. It is possible that the range of dietary NFC in the current study (from $40 \%$ to $50 \%$ of DM) was not wide enough to affect $\mathrm{OM}$ or $\mathrm{CP}$ intake. The differences in NFC of the diets were mainly due to the variance in NDF concentrations, which were $40 \%$ and $30 \%$ in the low and high NFC diet, respectively. However, Allen (2000) noted that no effect of NDF ranging from $25 \%$ to $40 \%$ was found on DM intake in dairy cows, although feed intake generally decreases with increasing NDF. Therefore, the lack of NFC/NDF effects on OM or CP intake might have been resulted from the fact that the diets were both iso-energetic and iso-nitrogenous.

\section{Nutrient digestibility}

Total-tract digestibility of OM was affected by NFC/NDF but not UDP. Although, it is generally accepted that ruminal microbes can better utilise diets of high NFC level, a corresponding increase in ruminal digestibility of OM was not observed. As digestibility is the result of digestion and passage rate, it could be inferred that these two factors were counterbalanced in the current study. On the other hand, it was reported that protein degradability hardly influenced OM digestion when the diets contained adequate CP (Cecava et al., 1991).

Total-tract digestibility of $\mathrm{CP}$ was not affected by either $\mathrm{NFC/NDF}$ or UDP. However, an effect of treatment interactions was observed on both ruminal and post-ruminal digestibility of CP. Generally, diets containing high levels of UDP or NFC have higher passage rates than those containing low levels of UDP or NFC/NDF, and therefore, the reduction of ruminal digestibility of $\mathrm{CP}$ when a high
UDP or NFC/NDF diet was fed could be expected.

Increase in NFC/NDF depressed the ruminal digestibility of NDF in the current study. Supplemental NFC had negative effects on NDF digestion because of the associated reduction in ruminal $\mathrm{pH}$ (Mould and Ørskov, 1983), and the threshold below which cellulytic activity would be inhibited was approximately 6.0 (Mould et al., 1983). The observed ruminal $\mathrm{pH}$ in lambs fed high NFC diets was below 6.0 for most of the time, which could explain the corresponding decrease in ruminal digestibility of NDF. Nevertheless, total-tract digestibility of NDF was compensated for by the increased post-ruminal digestibility of NDF, which resulted in the unaffected total tract digestibility of NDF by treatments. The large intestine has an active microbial population that can effectively degrade fibre, and it was reported that delignified postruminal digesta was hydrolysed by caecal microflora (Bailey and Macrae, 1970). On the other hand, a high proportion of NFC in the hind-gut may stimulate the growth of microbes, which might largely explain the increase in post-ruminal digestibility of NDF observed for high NFC diets.

\section{Ruminal fermentation characteristics}

Lambs fed high NFC/NDF diets displayed a sharper decrease in ruminal $\mathrm{pH}$ after each feeding, and similar patterns were also reported in heifers (Pina et al., 2009) and dairy cows (Agle et al., 2010). It is obvious that high NFC/NDF diets provided more fermentable carbohydrate for microbes to produce organic acids and, in addition, decreased saliva secretion due to the reduction in rumination time, which collectively led to the reduction of $\mathrm{pH}$.

The ruminal concentration of $\mathrm{NH}_{3}-\mathrm{N}$ was affected by NFC/NDF and UDP, as well as their interactions. Similar to the studies conducted by Pina et al. (2009) in beef heifers, low dietary UDP resulted in a higher ruminal $\mathrm{NH}_{3}-\mathrm{N}$ concentration because more degraded $\mathrm{N}$ was supplied to ruminal microbes. A higher $\mathrm{NH}_{3}-\mathrm{N}$ was found in low $\mathrm{NFC/NDF}$ diets compared with high NFC/NDF diets in the present study, which is in accordance with studies in dairy cows demonstrating that the provision of fermentable carbohydrates reduced ammonia production by reducing deamination or enhancing microbial capture of released ammonia in the rumen (Hristov et al., 2005).

The total ruminal VFA was higher for lambs fed high NFC/NDF diets (average $104.30 \mathrm{mmol} / \mathrm{L}$ ) than those fed low NFC/NDF (average $94.76 \mathrm{mmol} / \mathrm{L}$ ) diets. Ruminal concentrations of total VFA are in agreement with values reported with sheep under similar dietary conditions (Ramos et al., 2009). Ma et al. (2014) also proved that high dietary level NFC could improve ruminal concentration of total VFA. Increasing NFC decreased the molar proportion of acetate but increased that of propionate, which is similar 
to those reported by Carro et al. (2000). However, Ramos et al. (2009) found the molar proportion of acetate decreased with increasing NFC. Factors such as feeding regimes (e.g., time and amount) and sampling time could contribute to the discrepancy in ruminal VFA profiles in the abovementioned studies. Higher butyrate concentration was found when lambs were fed diets with higher NFC, which was consistent to those reported by Ma et al. (2014).

\section{Duodenal N metabolism}

$\mathrm{MN}$ was increased with increasing NFC/NDF and decreasing UDP. As more concentrate is offered, more fermentable carbohydrates are available for ruminal microbes to synthesise microbial protein when the dietary protein supply is equal. The $\mathrm{MN}$ was improved by an average of $20 \%$ (27\% in low NFC/NDF diet and $17 \%$ in high NFC/NDF diet) when the dietary level of UDP decreased from $54 \%$ to $38 \%$ of $\mathrm{CP}$ in the current study. However, no effect of level of UDP on MN was observed by Pina et al. (2009) in heifers. The microbial marker or flow marker used for calculating $\mathrm{MN}$ could partially be responsible for the differences between their study and ours. On the other hand, the low concentrate diet $(20 \%)$ used in their study could, to some extent, have limited the use of RDP by microbes, resulting in insignificant MN yield.

The protein requirement for ruminants is expressed in terms of metabolisable protein (MP) to depict the true protein absorbed from the small intestine, including microbial protein from the rumen and UDP (National Research Council, 2007). The duodenal digestibility of microbial protein is difficult to measure, and often constants are used. In addition, no standard methods exist for measuring duodenal digestibility of undegraded protein. Therefore, MP, in most cases, is represented using theoretical values rather than determined values. In this context, the metabolisable $\mathrm{N}$ measured in our study could to some extent better reflect the utilisation of protein by lambs. In the current study, lambs fed a high concentrate and UDP diet had the highest metabolisable $\mathrm{N}$, ratio of metabolisable $\mathrm{N}$ to either digestible $\mathrm{N}$ or $\mathrm{N}$ intake, and excreted the lowest amount of urinary $\mathrm{N}$, indicating that balancing dietary carbohydrates and protein is important in maximising $\mathrm{N}$ utilisation and reducing $\mathrm{N}$ excretion.

\section{CONCLUSION}

An increase in dietary UDP reduced intake and ruminal digestibility of CP. Ruminal $\mathrm{NH}_{3}-\mathrm{N}$ decreased with increasing dietary UDP or NFC/NDF, and dietary treatment interactions were observed. Diets with high levels of NFC/NDF improved MN and metabolisable $\mathrm{N}$, as well as the ratio of metabolisable $\mathrm{N}$ to digestible protein or $\mathrm{N}$ intake and reduced urinary $\mathrm{N}$ output in lambs.

\section{CONFLICT OF INTEREST}

We certify that there is no conflict of interest with any financial organization regarding the material discussed in the manuscript.

\section{ACKNOWLEDGMENTS}

This study was conducted as part of the National Technology Program for the Meat Sheep Industry of China (Program No. nycytx-39) funded by the Ministry of Agriculture of the People's Republic of China and Special Fund for Agro-scientific Research in the Public Interest (201303143). All authors participated in the writing of the final draft of the manuscript and agreed with the final format. The authors state that there are no conflicts of interest.

\section{REFERENCES}

Agle, M., A. N. Hristov, S. Zaman, C. Schneider, P. M. Ndegwa, and V. K. Vaddella. 2010. Effect of dietary concentrate on rumen fermentation, digestibility, and nitrogen losses in dairy cows. J. Dairy Sci. 93:4211-4222.

Ahvenjärvi, S., A. Vanhatalo, and P. Huhtanen. 2002. Supplementing barley or rapeseed meal to dairy cows fed grass-red clover silage: I. Rumen degradability and microbial flow. J. Anim. Sci. 80:2176-2187.

Allen, M. S. 2000. Effects of diet on short-term regulation of feed intake by lactating dairy cattle. J. Dairy Sci. 83:1598-1624.

AOAC. 1990. Official Methods of Analysis. 15th edn. Assoc. Off. Agric. Chem., Washington, DC, USA.

Asman, W. A. H., M. A. Sutton, and J. K. Schjørring. 1998. Ammonia: Emission, atmospheric transport and deposition. New Phytol. 139:27-48.

Bailey, R. W. and J. C. MacRae. 1970. The hydrolysis by rumen and caecal microbial enzymes of hemicellulose in plant and digesta particles. J. Agric. Sci. 75:321-326.

Bartram, C. G. 1987. The Endogenous Protein Content of Ruminant Proximal Duodenal Digesta. Ph.D. Thesis, University of Nottingham, Nottingham, UK.

Cantalapiedra-Hijar, G., D. R. Yáñez-Ruiz, A. I. Martín-García, and E. Molina-Alcaide. 2009. Effects of forage: Concentrate ratio and forage type on apparent digestibility, ruminal fermentation, and microbial growth in goats. J. Anim. Sci. 87:622-631.

Carro, M. D., C. Valdés, M. J. Ranilla, J. S. González. 2000. Effect of forage to concentrate ratio in the diet on ruminal fermentation and digesta flow kinetics in sheep offered food at a fixed and restricted level of intake. Anim. Sci. 70:127-134.

Cecava, M. J., N. R. Merchen, L. L. Berger, R. I. Mackie, and G. C. Fahey. 1991. Effects of dietary energy level and protein source on nutrient digestion and ruminal nitrogen metabolism in steers. J. Anim. Sci. 69:2230-2243. 
Chaney, A. L. and E. P. Marbach. 1962. Modified reagents for determination of urea and ammonia. Clin. Chem. 8:130-132.

Clark, J. H., T. H. Klusmeyer, and M. R. Cameron. 1992. Microbial protein synthesis and flows of nitrogen fractions to the duodenum of dairy cows. J. Dairy Sci. 75:2304-2323.

Egan, A. R. and R. J. Moir. 1965. Nutritional status and intake regulation in sheep: I. Effects of duodenally infused single doses of casein, urea, and propionate upon voluntary intake of a low-protein roughage by sheep. Crop Pasture Sci. 16:437449.

Goering, H. K. and P. J. Van Soest. 1970. Forage fiber analysis: (Apparatus, reagents, procedures, and some applications). In: Agricultural Handbook no. 379. Agricultural Research Service, US Department of Agriculture, Washington, DC, USA.

Hall, M. B. 2000. Calculation of non-structural carbohydrate content of feeds that contain non-protein nitrogen. University of Florida (Bulletin 339), Gainesville, FL, USA. pp. A-25.

Hoekstra, N. J., R. P. O. Schulte, P. C. Struik, and E. A. Lantinga. 2007. Pathways to improving the $\mathrm{N}$ efficiency of grazing bovines. Eur. J. Agron. 26:363-374.

Hristov, A. N., J. K. Ropp, K. L. Grandeen, S. Abedi, R. P. Etter, A. Melgar, and A. E. Foley. 2005. Effect of carbohydrate source on ammonia utilization in lactating dairy cows. J. Anim. Sci. 83:408-421.

Kiran, D. and T. Mutsvangwa. 2007. Effects of barley grain processing and dietary ruminally degradable protein on urea nitrogen recycling and nitrogen metabolism in growing lambs. J. Anim. Sci. 85:3391-3399.

Lord, E. I. 1996. Pilot nitrate sensitive area scheme: Report of the first 4 years. In: Diffuse Pollution and Agriculture (Eds. Petchey, A. M., B. J. D'Arcy, and C. A. Frost). The Scottish Agricultural College, Aberdeen, UK. pp. 64-72.

Ma, T., K. D. Deng, C. G. Jiang, Y. Tu, N. F. Zhang, J. Liu, Y. G. Zhao, and Q. Y. Diao. 2013. The relationship between microbial $\mathrm{N}$ synthesis and urinary excretion of purine derivatives in Dorper $\times$ thin-tailed Han crossbred sheep. Small Rumin. Res. 112:49-55.
Ma, T., K. D. Deng, Y. Tu, N. F. Zhang, C. G. Jiang, J. Liu, Y. G. Zhao, and Q. Y. Diao. 2014. Effect of dietary forage-toconcentrate ratios on urinary excretion of purine derivatives and microbial nitrogen yields in the rumen of Dorper crossbred sheep. Livest. Sci. 160:37-44.

Mould, F. L. and E. R. Ørskov. 1983. Manipulation of rumen fluid $\mathrm{pH}$ and its influence on cellulolysis in sacco, dry matter degradation and the rumen microflora of sheep offered either hay or concentrate. Anim. Feed Sci. Technol. 10:1-14.

Mould, F. L., E. R. Ørskov, and S. O. Mann. 1983. Associative effects of mixed feeds: I. Effects of type and level of supplementation and the influence of the rumen fluid $\mathrm{pH}$ on cellulolysis in vivo and dry matter digestion of various roughages. Anim. Feed Sci. Technol. 10:15-30.

National Research Council. 2007. Nutrient requirements of small ruminants: Sheep, goats, cervids, and new world camelids. National Academies Press, Washington, DC, USA.

Pina, D. S., S. C. Valadares Filho, L. O. Tedeschi, A. M. Barbosa, and R. F. D. Valadares. 2009. Influence of different levels of concentrate and ruminally undegraded protein on digestive variables in beef heifers. J. Anim. Sci. 87:1058-1067.

Ramos, S., M. L. Tejido, M. E. Martínez, M. J. Ranilla, and M. D. Carro. 2009. Microbial protein synthesis, ruminal digestion, microbial populations, and nitrogen balance in sheep fed diets varying in forage-to-concentrate ratio and type of forage. J. Anim. Sci. 87:2924-2934.

Reynal, S. M. and G. A. Broderick. 2005. Effect of dietary level of rumen-degraded protein on production and nitrogen metabolism in lactating dairy cows. J. Dairy Sci. 88:4045-4064.

Stern, M. D., G. A. Varga, J. H. Clark, J. L. Firkins, J. T. Huber, and D. L. Palmquist. 1994. Evaluation of chemical and physical properties of feeds that affect protein metabolism in the rumen. J. Dairy Sci. 77:2762-2786.

Van Soest, P. J., J. B. Robertson, and B. A. Lewis. 1991. Methods for dietary fiber, neutral detergent fiber, and nonstarch polysaccharides in relation to animal nutrition. J. Dairy Sci. 74:3583-3597.

Volden, H. and O. M. Harstad. 1995. Effect of rumen incubation on the true indigestibility of feed protein in the digestive tract determined by nylon bag techniques. Acta Agric. Scand. A-AN. 45:106-115. 